\title{
Chapter 2 \\ Message to the Participants of the XXI Edoardo Amaldi Conference
}

\author{
Paul Richard Gallagher
}

Your Excellencies, distinguished Panelists, dear Ladies and Gentlemen,

It is a pleasure to address you with a brief message at the XXI Edoardo Amaldi Conference on International Cooperation for Enhancing Nuclear Safety, Security, Safeguards and Non-Proliferation.

Today's meeting is very pertinent, given the difficulties that we are unfortunately witnessing in the field of arms control and, in particular, nuclear weapons disarmament and non-proliferation.

As mentioned recently by His Eminence Card. Pietro Parolin, the Holy See's Secretary of State, at the General Assembly High-Level Plenary Meeting to commemorate and promote the International Day for the Total Elimination of Nuclear Weapons (New York, 26 September 2019), "the lapse of the Intermediate-Range Nuclear Forces Treaty, the failure to achieve entry into force of the Comprehensive Nuclear-Test-Ban Treaty, the inability of the Conference on Disarmament even to begin negotiations on a ban on the production of fissile material for nuclear weapons, the so-called "modernization" of nuclear weapons and delivery systems, and the instabilities at play in the implementation of the Joint Comprehensive Program of Action [...] are worrying signs of an erosion of multilateralism and of the ruled-based order [...] One might be tempted to lose hope in face of the setbacks, the impasse or the very slow progress in the disarmament agenda, in particular in the area of nuclear disarmament. However, perseverance and determination should characterize our common efforts to move toward the elimination of nuclear weapons. We must make every effort to avoid dismantling the international architecture of arms control, especially in the field of weapons of mass destruction".

The Holy See is totally committed in this effort. This is demonstrated by the fact that it is Party to the main multilateral Treaties concerning nuclear weapons:

P. R. Gallagher $(\bowtie)$

Holy See's Secretariat of State, Vatican City, Holy See

e-mail: rapportistati@sds.va 
the Treaty on the Non-Proliferation of Nuclear Weapons (NPT), the Comprehensive Nuclear-Test-Ban Treaty (CTBT), and the Treaty on the Prohibition of Nuclear Weapons. Each is a component of the international regime of nuclear disarmament and non-proliferation, which also includes the IAEA Safeguards Agreements and related Additional Protocols, the Agreements for nuclear-weapons-free zones, as well as various other bilateral agreements. All of them play a complementary role in the difficult path to achieve the long-term and complex goal of a nuclear weapons free world, desired by the whole international community.

The common goal of a nuclear free world was underlined by Pope Francis at a symposium held at the Vatican in November 2017, where he emphasized that nuclear weapons exist "in the service of a mentality of fear that affects not only the parties in conflict but the entire human race. International relations cannot be held captive to military force, mutual intimidation, and the parading of stockpiles of arms. Weapons of mass destruction, particularly nuclear weapons, create nothing but a false sense of security. They cannot constitute the basis for peaceful coexistence between members of the human family, which must rather be inspired by an ethics of solidarity".

Your Excellencies,

At the recent XI Conference to facilitate the entry into force of the Comprehensive Nuclear-Test-Ban Treaty (New York, 25 September 2019), Card Parolin said that "the norms embodied in the UN Charter, international humanitarian law, disarmament and arms control instruments, and other elements of international law represent an indispensable commitment to cooperative security and a juridical embodiment of this global ethic of responsibility that is now sorely needed".

The Holy See has indeed often reaffirmed in international forums on disarmament the importance of concretely promoting the culture of life and peace, founded on the dignity of the human being and on the primacy of law, through a multilateralism based on dialogue and the responsible, honest cooperation of all members of the community of nations. These are indispensable elements for the construction of real and lasting trust, a fundamental element for guaranteeing international security and peace.

We must work tirelessly to restore any possibility of dialogue and to fight the trustdeficits, which unfortunately characterize the current environment around nuclear disarmament and non-proliferation, especially since strengthening dialogue and rebuilding trust to be one of the major aims of this thought-provoking Conference.

With this in mind, I would like to recall what was said by Pope Francis in His Message to the United Nations Conference to Negotiate a Legally Binding Instrument to Prohibit Nuclear Weapons, Leading Towards Their Total Elimination on $27 \mathrm{March}$ 2017: "Growing interdependence and globalization mean that any response to the threat of nuclear weapons should be collective and concerted, based on mutual trust. This trust can be built only through dialogue that is truly directed to the common good and not to the protection of veiled or particular interests; such dialogue, as far as possible, should include all: nuclear states, countries which do not possess nuclear weapons, the military and private sectors, religious communities, civil societies, and international organizations. And in this endeavour we must avoid those forms of mutual recrimination and polarization which hinder dialogue rather than encourage 
it. Humanity has the ability to work together in building up our common home; we have the freedom, intelligence and capacity to lead and direct technology, to place limits on our power, and to put all this at the service of another type of progress: one that is more human, social and integral".

Thank you.

Open Access This chapter is licensed under the terms of the Creative Commons Attribution 4.0 International License (http://creativecommons.org/licenses/by/4.0/), which permits use, sharing, adaptation, distribution and reproduction in any medium or format, as long as you give appropriate credit to the original author(s) and the source, provide a link to the Creative Commons license and indicate if changes were made.

The images or other third party material in this chapter are included in the chapter's Creative Commons license, unless indicated otherwise in a credit line to the material. If material is not included in the chapter's Creative Commons license and your intended use is not permitted by statutory regulation or exceeds the permitted use, you will need to obtain permission directly from the copyright holder.

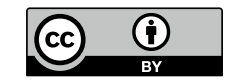

